\title{
Irish-Dutch Sandwiches, Corporate Inversions, and Arm's Length Transactions: International Tax for IB Courses
}

\author{
James Nebus, Suffolk University, USA
}

\section{Introduction}

Looking for a good reason to introduce international tax into your IB course? Let me give you five. First, every IB course includes a unit whose purpose is to have students appreciate how doing business differs when traversing borders - tax is certainly a practical example of this. Second, all MNEs must submit tax returns, and therefore managers must understand, at least at a high level, the general classes of tax systems and principles that countries employ. Third, international tax is a provocative, controversial topic which will engage students academically and often emotionally. Students read in the practitioner press about large MNEs that pay little or no tax, and students want to know: How do they do it? Why are they getting away with it? Fourth, tax is a relevant example by which to discuss MNE-government bargaining and relations. A discussion of tax includes the ability of MNEs to play countries against each other. Fifth, tax is an issue area that can be used as a context when teaching global governance. Actions to assure that each MNE pays its "fair share" of tax require broad international support and exchange of information among countries, MNEs, and supranational organizations. Given this premise, it is not surprising that international tax reforms are complex and slow in developing. to watch an investigative reporting piece, available online, that provides both the MNE and government perspectives on the international tax issue. The 60 Minutes piece (CBS, 2011) is a few years old but gives students a high-level introduction and an appreciation for the subject as a contemporary, relevant issue and conveys the frustration of both MNE CEOs and governments with the current tax system. I also assign an article from the practitioner press (Economist, 2013, 2014) on MNEs that pay little or no tax, along with a current headline story in a financial newspaper, such as the Pfizer-Allergen merger (Hoffman, 2015). These assignments (module (1) in Figure 1) "set the hook" and students come into class eager to learn more details.

\section{Tax Basics}

When introducing international tax, I suggest you think of the topic as comprised of two categories: transfer pricing and corporate tax on foreign sourced income (2) in Figure 1). That way, if you don't have time to address both, you can teach either one somewhat independently of the other. Intracompany transfer pricing is, in theory, based on the principle of arm's length transactions, in which intracompany prices are set as if the transferred product is an intercompany sale (Eden, 1998, 2015). The effect of different transfer prices on MNE subsidiary and overall corporate profits is relatively straightforward for students when discussing physical products. However,

There is no shortage of materials and methods that are available to IB instructors that facilitate introducing international tax into your IB course. These include cases, videos, simulations, academic book chapters on tax theory, as well as numerous articles in the practitioner press and by multinational organizations which reflect a variety of different perspectives and agendas. Debates are a particularly effective way of both engaging students and teaching both sides of the issues. No one is without an opinion on tax avoidance, tax arbitrage, and tax havens.

\section{Teaching International Tax}

Prior to the class lecture on tax, I introduce the topic by asking students transfer pricing enters a "grey area" when you introduce intangible assets and MNE income shifting activities and structures. One example of this tax avoidance structure is the "double Dutch-Irish sandwich" (Figure 2), in which a parent company's IP is transferred at a low value to an Irish incorporated subsidiary located in a tax haven, who in turn licenses the IP under a royalty agreement to an operating company in Ireland, and the Irish operating company then funnels royalty payments back to the Irish subsidiary through an intermediate company in the Netherlands (Fuest, Spengel Finke, Heckemeyer, \& Nusser, 2013; UNCTAD, 2015). The intermediate company is inserted as the Netherlands does not impose withholding taxes on royalty payments. Students are first curious to know how this works, and then shocked that MNEs can do this to avoid tax. 
Figure 1. Taxation Course Module Sequence

(1) Homework Assignments Prior to First Class on Int'l Tax

I assign students to read, or watch, the following:

1. One overview article from the business press (e.g., parts of Economist, 2013)

2. One video that shows how the tax issue draws emotional reactions from both country governments and MNE CEOs (e.g., CBS, 2011)

3. A news article that conveys the issue's contemporary relevance (Hoffman, 2015)

(2) First Class on Int'l Tax - Lecture on Concepts, Laws, Tax Analysis

1. Transfer pricing (TP)

- What is a TP? Why is it required? Who sets it? TP and arm's length transactions

- How TP affects subsidiary profits and MNE overall worldwide profit

- Potential issues with intangible assets

2. Corporate Taxation of Foreign Sourced Income

- Country maximum corporate tax rates versus effective tax rates

- Territorial tax systems versus Worldwide tax systems (US)

- Credits for Foreign Tax Paid; Interest and R\&D Allocations against Income

- Repatriation timing issues and taxation consequences

- Tax policy that incents MNE investment and job creation outside home country

- Excess credit versus Deficit credit firms and influence on investment decisions

3. Corporate Inversions and Tax Havens

- What is a tax haven? What is an inversion?

- What are the incentives to do an inversion? Pre and post inversion profit analysis

- Recent laws to attempt to stop inversions

(3) Homework Assignments Prior to Second Class on Int'I Tax

- All students read the case "Corporate inversions: Stanley works and the lure of tax havens" (Desai et al., 2002)

- First group of students is assigned to present case analysis to class

- Second group of students is asked to prepare a presentation on the view of country governments in answering the questions: Are MNE's paying their fair share? If not, who is to blame? What should be done about it?

- Third group of students is asked to prepare the MNE's view on these questions

(4) Second Class on Int'l Tax - Presentations, Debate, Conclusion

- First student group presents their case analysis

- Second and third groups present their viewpoints, followed by debate, discussion

- I summarize and conclude by pointing to areas of blame on both sides

(5) Ongoing Simulation with Transfer Pricing Decisions

A component of my IB course is the Cesim Global Challenge Simulation. Students make weekly decisions on running an MNE including setting transfer prices from product source to destination countries given subsidiary profits and country tax rates. 
Another tool I use for teaching transfer pricing is simulation (module (5) in Figure 1). While examples of transfer pricing of physical goods between MNE units in two countries are easy to understand, they do not enable students to appreciate the complexity involved in deciding on a set of transfer prices from units in several source countries to several destination countries. The Cesim Global Challenge simulation (Cesim, 2015) requires students to make these transfer pricing decisions, with the goal of optimizing overall MNE profit, for three destination countries that may sell up to four products from two possible source countries, given each country's corporate tax rate and tariff and transportation costs among them.

I start out the topic of corporate tax by distinguishing between country maximum corporate tax rates and country effective tax rates. Students often fixate on the US having the highest maximum corporate tax rate. However, the US's effective tax rate is less than a country like Brazil, which has a lower maximum corporate tax rate but has fewer deductions as well as higher state taxes and a social contribution tax. Next, I explain the differences between tax laws in countries which have a territorial tax regime, in which tax is calculated only on income earned in that country, versus worldwide tax systems, in which all of a home country MNE's income is taxed, including income generated in other countries. However, in worldwide tax systems such as the US, foreign income is only taxed when it is repatriated and then a tax credit is given on taxes paid to other countries.

Worldwide tax systems have several perverse effects, such as home country MNEs not repatriating profits to avoid taxes and instead reinvesting profits outside the home country. This has, for example, resulted in many US high technology MNEs having more assets and employees outside the US than in it. In an economic climate where there is much emphasis on job creation, US students are typically perplexed and dismayed that archaic US tax laws are an incentive for US MNEs to create more jobs outside the US than in it. It is also important to explain that in some worldwide tax system countries as the US, MNEs must allocate some expenses, such as interest payments and R\&D expenses, based on percent of total assets abroad, even though these expenses were incurred in the home country. Finally, it is instructive to differentiate between excess credit firms, whose foreign tax rate is greater than the home country tax rate, and deficit credit firms. These two MNE tax credit positions result in FDI target countries providing different investment incentives. Primers by Reiling (2006) and Desai (2005) are recommended reading as background material for instructors not familiar with MNE taxation.

\section{Tax Avoidance}

After these basics of corporate income tax law, I turn the students' attention to what MNEs do to avoid taxes. This leads to an explanation of "corporate inversions," an MNE from a worldwide tax system home country "changing" its home country by moving its headquarters to a tax haven. The net tax effect of an inversion is that now taxes paid to what was previously the home country are based only on income earned in that country. The MNE now does not have to pay taxes to what was previously its home country on the income of the its foreign subsidiaries, and the tax haven has no corporate taxes. After the first class, I assign the case "Corporate Inversions: Stanley Works and the Lure of Tax Havens" (Desai, Hines, \& Veblin, 2002) to help students compare the before and after effects of a corporate inversion (3) in Figure 2). This case also has an excellent teaching note. My case analysis assignment asks students to calculate the tax before and after the inversion and argue whether the firm should do the inversion or not. At the undergraduate level, I keep students on track by providing spreadsheet templates for calculations with data from the exhibits.

For the next class (4) in Figure 1), I ask half the class to prepare to take the position of MNEs and the other half to take the position of governments and ask them to debate these questions: Who is to blame for MNEs not paying their "fair share"? What should be done about it? This is usually a raucous, finger-pointing affair, but it is rewarding to see students teach each other in the process.

At the end, I point out that in reality there is plenty of blame to go around on both sides. I explain that while economists can prescribe changes to tax law that will simultaneously force MNEs to pay their "fair share," increase government tax revenues, and create jobs in the home country in the long run, these prescriptions often have the side effect of tax revenue shortfalls in the short run. For example, reducing corporate taxes on repatriated income for US MNEs will increase MNE investment in the US and create more jobs in the US, both of which will increase tax revenues in the long run. However, there will be a lag, perhaps as much as five years, between the time the tax law passes and the time the resulting new investments are paying enough tax to more than compensate for the tax rate reduction. In the meantime, the consequence of the law will be an immediate tax revenue shortfall as the taxes paid by existing MNEs is decreased. I explain that while the "long term" to an economist might be a decade or two, the long term to a politician is the next election.

The statement of previous EU Council president Claude Junker regarding politicians and the debt problem equally applies to the tax problem: "We all know what to do [economically], we just don't know how to get re-elected after we've done it." Therefore, because of a reluctance to overhaul the tax code, we observe a continuous cycle of (1) MNEs exploit a loophole in the tax code to reduce taxes, (2) governments pass tax legislation to plug the loophole, (3) MNE tax lawyers find another loophole in the tax code, and (4) go to step 1.

\section{Discussion and Conclusion}

In my view, there are several reasons why fewer students, aside from those in tax specialty masters programs, are exposed to international tax in business schools. First, IB professors are quick to delegate the tax topic to their accounting departments, while most accounting departments, at least in the US, focus on the details of domestic tax 
law. Second, less tax research finds its way into classrooms as IB professors who are interested in tax research find it difficult to publish in IB journals. This is because our IB/strategy journals find articles on tax policy to be atheoretical and more oriented for a practitioner than for an academic audience. Ironically, many of these same journals, which might be considered to have a disproportionate emphasis on academic writing at the expense of practical impact, then have special issues which ask the question: Why aren't business practitioners listening to business academics? This is unfortunate as a conversation on alternative tax regimes in our literature could make a significant contribution to renovating tax policy, thereby breaking the aforementioned cycle of legislative band aids on tax loopholes.

In my view, the root cause underlying tax issues is that profit is the basis of taxation, and the profit metric is not transparent, can be easily shifted geographically, and is subject to creative accounting. A more objective and transparent tax metric, such as changes in stock price, which reflects profits but cannot be shifted geographically, would eliminate MNEs' motivation to locate in tax havens. Tax havens would simply dry up and go away. These alternative bases of taxation introduce another set of problems, but that is a discussion for another paper.

In the meantime, I strongly urge you to introduce international tax into your IB course. You might be rewarded, as I have, when a student stops you in the hallway the following semester and says "Hello, Professor. By the way I read an article in the financial newspaper last week about offshore financing, and I actually understood it!"

\section{Appendix: Resources for Educators}

There are a wide variety of international tax educational resources available. Short primers on international tax for IB instructors include Reiling (2006) and Desai (2005). For student analysis, presentation, and discussion, I use the Harvard case "Corporate Inversions: Stanley Works and the Lure of Tax Havens" (Desai, Hines, \& Veblen, 2002), which has an accompanying teaching note (Desai, Veblen, \& Luchs, 2005). Chapter 13 of Pratt and Kulsrud's (2016) taxation textbook is a well written introduction to international taxation.

For instructors who want a more detailed understanding, suggested textbooks dedicated to international tax include Bittker and Lokken (2014) and Doernberg (2012). More academic treatments of taxation can be found in Eden $(1998,2016)$ and Fuest et al. (2013). In addition, Webb (2006) presents an academic global governance perspective on international taxation. Chapter V of UNCTAD's 2105 World Investment Report contains a good discussion of the problems of present corporate tax law and its impact on the economic development of emerging economies.

In order to initially convey the tax issues and positions of stakeholders to students, I use the 13-minute video from the 60 Minutes news reporting show by CBS (2011). Beyond that, the business press offers a number of overview articles (e.g., Economist, 2013) on the impact of corporate tax laws. In addition, the financial newspapers have a constant stream of short reports on company and political news that illustrate the contemporary relevance of this topic (e.g., Hoffman, 2015). Finally, business simulations provide an engaging resource for students who actively learn by making weekly decisions while managing an MNE over the semester and then understanding the consequences of these decisions from their firms' results. The Cesim Global Challenge (2015) simulation requires students to set transfer prices and thereby appreciate their impact on an MNE with multiple product source and destination countries, each with different tax rates.

\section{References}

Bittker, B., Lokken, L. 2014. Fundamentals of international taxation. Valhalla, NY: Thomson Reuters.

CBS. 2011. The new tax haven. 60 Minutes. https://www.youtube.com/ watch?v=MxgezC4KhXQ. Accessed December 14, 2015.

Cesim. 2015. Cesim Global Challenge Simulation. http://www.cesim.com.

Desai, M. 2005. Note on international tax regimes. Harvard Business School, 9-206-014.

Desai, M., Hines, J., \& Veblen, M. 2002. Corporate inversions: Stanley Works and the lure of tax havens. Harvard Business School, 9-203-008.

Desai, M., Veblen, M., Luchs, K. 2005. Teaching note on corporate inversions. Harvard Business School. 5-206-013.

Doernberg, R. 2012. International taxation in a nutshell. St. Paul, MN: West Publishing.

Economist. 2013. Special Report: Offshore finance. February 16: 1-16.

Economist. 2014. Big economies take aim at firms running circles around their tax men. September 20.

Eden, L. 1998. Taxing multinationals: Transfer pricing and corporate income taxation in North America. Toronto: University of Toronto Press.

Eden, L. 2016. The arm's length standard: Making it work in a $21^{\text {st }}$ century world of multinationals and nation states. In T. Pogge \& K. Mehta (Eds.), Global Tax Fairness. Oxford: Oxford University Press.

Fuest, C., Spengel, C., Finke, K., Heckemeyer, J., \& Nusser, H. 2013. Profit shifting and "aggressive" taxplanning by multinational firms: Issues and options for reform. Center for European Economic Research, Mannheim, No. 13-04.

Hoffman, L. 2015. Taxes drives potential merger of Pfizer, Allergen. Wall Street Journal, October 29

Pratt, J., \& Kulsrud, W. 2016. Corporate, Partnership, Estate, \& Gift Tax. Cincinnati, $\mathrm{OH}$ : Van Griner.

Reiling, M. 2006. U.S. taxation offoreign-source corporate income. Harvard Business School. 9-207-085. 
UNCTAD. 2015. Chapter V: International Tax and Investment Policy Coherence. In World Investment Report 2015: 175-218. Geneva: United Nations Press.

Webb, M. 2006. Shaping international corporate taxation. In C. May (Ed.), Global Corporate Power. London: Lynne Rienner Publishers.
James Nebus (jnebus@suffolk.edu) is an Assistant Professor of Strategy and International Business and Director of the Undergraduate Global Business Program at Suffolk University in Boston, US. He has published in the Journal of International Business Studies, Academy of Management Review, and Journal of International Management among others. He has 22 years of industry experience including 10 years in international management positions in Europe and Asia.

Figure 2. Double Irish-Dutch Sandwich

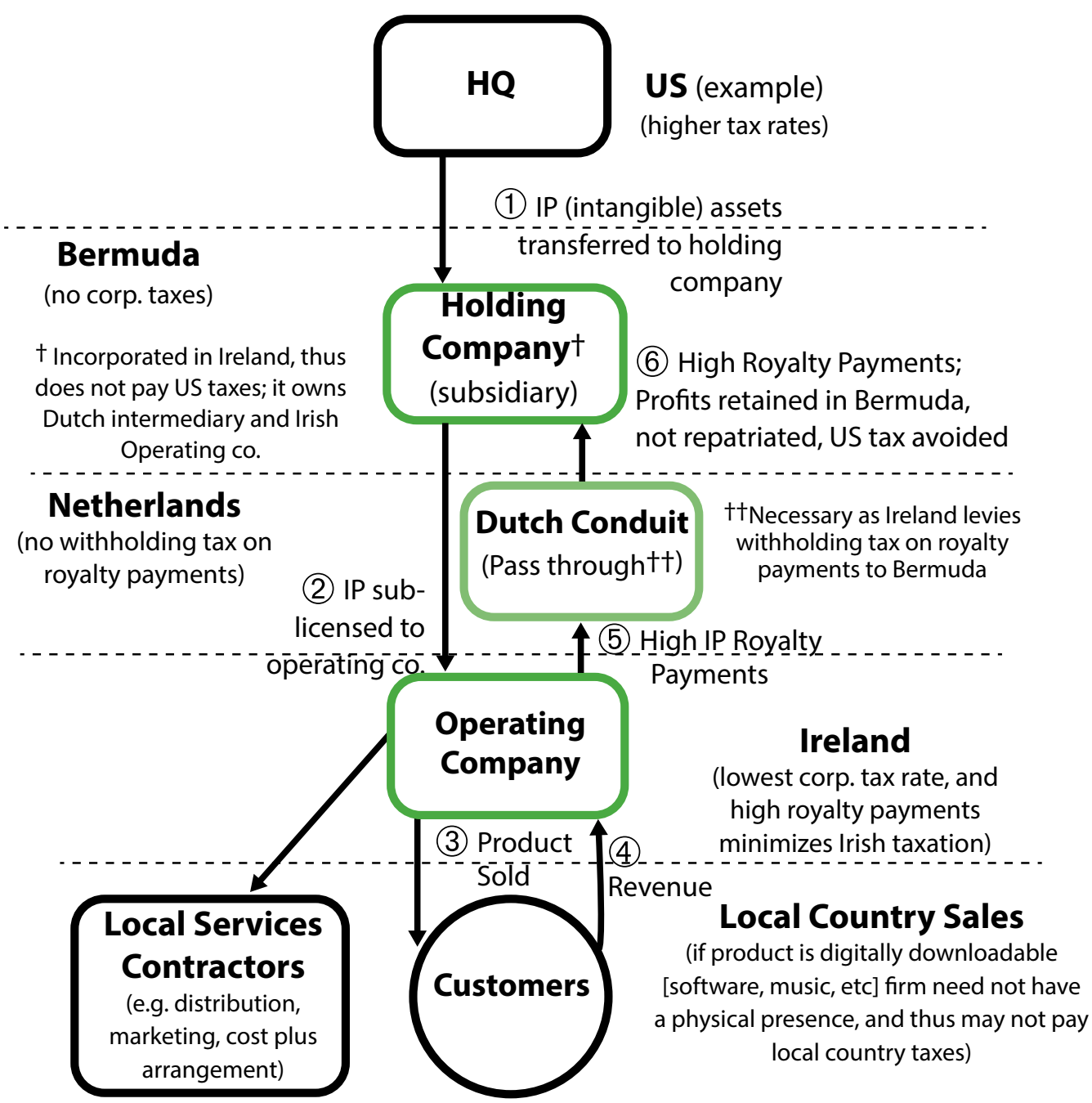

